\title{
PHASE AND MICROSTRUCTURE DEVELOPMENT OF LSCM PEROVSKITE MATERIALS FOR SOFC ANODES PREPARED BY THE CARBONATE-COPRECIPITATION METHOD
}

\author{
RAZVOJ KRISTALNIH FAZ IN MIKROSTRUKTURE LSCM \\ PEROVSKITNIH MATERIALOV ZA SOFC ANODE, \\ PRIPRAVLJENIH S KARBONATNO METODO KOPRECIPITACIJE
}

\author{
Klementina Zupan, Marjan Marinšek, Tina Skalar \\ University of Ljubljana, Faculty of Chemistry and Chemical Technology, Večna pot 113, 1000 Ljubljana, Slovenia \\ klementina.zupan@fkkt.uni-lj.si
}

Prejem rokopisa - received: 2015-07-21; sprejem za objavo - accepted for publication: 2015-10-09

doi:10.17222/mit.2015.232

\begin{abstract}
Most SOFC development has been based on nickel yttria-stabilized zirconia anodes. Such materials have excellent catalytic properties for fuel oxidation, high electrical conductivity, good mechanical strength and an appropriate thermal expansion coefficient compatible with other cell components. Unfortunately, cermet anodes based on doped zirconia exhibit some disadvantages, e.g., the catalysing side reaction of carbon deposition during hydro-carbon fuel oxidation and a susceptibility to sulphur poisoning. Perovskite-type compounds based on lanthanum-strontium-manganese-chromium oxide (LSCM) can serve as an alternative material. Since the optimal perovskite composition is still not known, $\mathrm{La}_{1-\mathrm{x}} \mathrm{Sr}_{\mathrm{x}} \mathrm{Mn}_{\mathrm{y}} \mathrm{Cr}_{1 . \mathrm{y}} \mathrm{O}_{3 \pm \delta}(x$ from 0 to 0.3 and $y$ from 0.4 to 0.6 ) ceramics were prepared with the co-precipitation method. Crystalline phase formation was followed by X-ray powder diffraction and Rietveld refinement. Quantitative microstructure analysis of the samples sintered at various temperatures was performed on SEM micrographs using Axiovision 4.8 software.
\end{abstract}

Keywords: co-precipitation, oxide LSCM anode, phase development, microstructure

Večina razvoja visokotemperaturnih gorivnih celic je temeljila na anodnih materialih na osnovi niklja in cirkonijevega dioksida, stabiliziranega z itrijem. Ta ima odlične katalitske lastnosti pri reakciji oksidacije goriva, visoko električno prevodnost, dobro mehansko trdnost in temperaturni razteznostni koeficient, skladen $\mathrm{z}$ ostalimi komponentami celice. Žal so ti materiali med delovanjem podvrženi neželenim reakcijam izločanja ogljika in zastrupljanja z žveplom, zato jih poskušamo nadomestiti z oksidnimi spojinami perovskitnega tipa, $\mathrm{z}$ lantan-stroncij-mangan-krom oksidom (LSCM). Optimalna sestava teh materialov še ni znana, zato smo $\mathrm{Z}$ metodo soobarjanja pripravili keramiko $\mathrm{La}_{1-\mathrm{x}} \mathrm{Sr}_{\mathrm{x}} \mathrm{Mn}_{\mathrm{y}} \mathrm{Cr}_{1 . \mathrm{y}} \mathrm{O}_{3 \pm} \delta$ ( $x$ od 0 do 0,3 in $y$ od 0,4 do 0,6 ). $\mathrm{Z}$ rentgensko praškovno analizo in Rietveldovim prilagajanjem smo spremljali razvoj kristalnih faz. $Z$ analizo SEM posnetkov vzorcev po sintranju pri različnih temperaturah smo mikrostrukture pripravljenih materialov kvantitativno ovrednotili z uporabo programa Axiovision 4.8

Ključne besede: kopercipitacija, oksidna LSCM anoda, razvoj faz, mikrostruktura

\section{INTRODUCTION}

Fuel cells can be considered as devices that electrochemically convert fuels into electricity or, more precisely, batteries with permanent fuel supplies. Solid-oxide fuel cells (SOFCs), based on an ion-conducting electrolyte, have several advantages over other types of fuel cells, including their potential fuel flexibility and very high chemical-to-electrical conversion efficiency due to the absence of Carnot limitations. Further energy gains can be achieved in SOFC systems when cogenerated heat is used for the internal reforming of methane or other hydrocarbon fuels directly on the anode. ${ }^{1}$

Porous Ni/YSZ-based materials are conventionally used as SOFC anodes due to their high electrical conductivity, activity for electrode electro-chemical oxidation, stability under reduced environmental conditions, appropriate thermal expansion and a chemical compatibility with other cell components. ${ }^{2}$ Despite the many advantages they possess, there are some drawbacks, such as a low tolerance to sulphur impurities ${ }^{3}$ and a tendency to coke when hydrocarbons are used as fuels ${ }^{4}$.

Alternative cermet anode materials have been extensively studied, such as $\mathrm{Cu}-\mathrm{CeO}_{2}$-YSZ. Researchers have demonstrated their operation using various fuels., Recently, another alternative approach aiming to prepare all-oxide anode materials has been proposed in order to develop electrodes that exhibit catalytic, electron- and ion-conducting properties. Many problems with all-oxide anodes have been overcome with the introduction of novel perovskite-structure materials with the general formula $\mathrm{ABO}_{3-\delta}$. The $\mathrm{A}$ element is typically lanthanide, while the $\mathrm{B}$ element is the transition metal. In principle, catalytic activity toward fuel oxidation, electron- and ion-conductivity can be tailored by a wide range of doping elements. The oxidation states of the A-site and B-site cations determine the oxygen vacancy concentration $\delta .{ }^{2}$ Among various perovskites, a particularly complex metal oxide with the composition $\mathrm{La}_{0,75} \mathrm{Sr}_{0,25} \mathrm{Mn}_{0,5} \mathrm{Cr}_{0,5} \mathrm{O}_{3-\delta}$ has attracted much attention as a 
promising anode material, due to its good catalytic activity, excellent redox stability, reduced carbon deposition susceptibility and improved sulphur-poisoning stability. ${ }^{7}$ An introduction of alkaline earth ions, i.e., $\mathrm{Mg}^{2+}, \mathrm{Ca}^{2+}$, and $\mathrm{Sr}^{2+}$, into the A site of lanthanum chromite can enhance the electrical conductivity by two orders of magnitude. ${ }^{7}$ L. Deleebeck et al. ${ }^{9}$ first demonstrated that the removal of $\mathrm{Sr}$ from $\mathrm{La}_{1-\mathrm{x}} \mathrm{Sr}_{\mathrm{x}} \mathrm{Mn}_{1-\mathrm{y}} \mathrm{Cr}_{\mathrm{y}} \mathrm{O}_{3 \pm \delta}$ improves the thermo-chemical stability and the electronic conductivity in a humidified $\mathrm{H}_{2}$ atmosphere. In their second study, they reported that the catalytic activity toward $\mathrm{H}_{2}$ oxidation decreases with increasing $\mathrm{Cr}$ content $(y=0.4-0.6)$, while the relatively high $\mathrm{Sr}$ content $(x=0.2)$ shows a lower catalytic activity. ${ }^{10}$ The optimal LSCM material composition is not yet known.

Various chemical routes to prepare LSCM powders have been reported, including the solid-state reaction, ${ }^{7}$ the chelating method, ${ }^{11}$ gel casting, ${ }^{12}$ and combustion synthesis. ${ }^{13-16}$ However, the synthesis of single-phase LSCM composed of fine powders requires a further improvement. Co-precipitation is a promising and simple chemical method to prepare well-defined and less-agglomerated perovskite powders. It was reported that the most significant synthesis parameter for LSCM preparation via co-precipitation is the $\mathrm{pH}$ value of the reaction mixture, which should be maintained slightly below 8 in order to ensure that all the cations precipitate. ${ }^{17}$ In addition to an appropriate chemical composition of the LSCM material, the electrode performance in an operating SOFC is also essentially dependent on the electrode microstructure, final porosity and potential presence of secondary phases.

In this work, we applied the "reverse strike" carbonate co-precipitation method for batch $\mathrm{La}_{1-\mathrm{x}} \mathrm{Sr}_{\mathrm{x}} \mathrm{Mn}_{1-\mathrm{y}} \mathrm{Cr}_{\mathrm{y}} \mathrm{O}_{3 \pm \delta}$ perovskite preparation in which the $\mathrm{Sr}$ content and the Cr-to-Mn molar ratio were varied. The aim of this work is to describe the relationship between the microstructure parameters and the LSCM composition using various analytical techniques.

\section{EXPERIMENTAL PROCEDURE}

$\mathrm{La}_{1-\mathrm{x}} \mathrm{Sr}_{\mathrm{x}} \mathrm{Mn}_{1-\mathrm{y}} \mathrm{Cr}_{\mathrm{y}} \mathrm{O}_{3 \pm \delta}(x=0,0.1,0.2$ or 0.3 and $y=$ $0.4,0.5$ or 0.6 ) oxides were prepared using co-precipitation synthesis (Table 1). $\mathrm{La}\left(\mathrm{NO}_{3}\right)_{3} \cdot 6 \mathrm{H}_{2} \mathrm{O}$ (99 \%), $\mathrm{Sr}\left(\mathrm{NO}_{3}\right)_{2} \quad(98 \%), \quad \mathrm{Cr}\left(\mathrm{NO}_{3}\right)_{3} \cdot 9 \mathrm{H}_{2} \mathrm{O} \quad(98.5 \%)$ and $\mathrm{Mn}\left(\mathrm{NO}_{3}\right)_{2} \cdot 4 \mathrm{H}_{2} \mathrm{O}(98 \%)$, all from Alfa Aesar, were used as the source of metal ions. The carbonate precursors were prepared using the "reverse strike" method in which a mixed metal nitrate solution is added to a precipitant carbonate solution to achieve a more uniform cation distribution by instantaneous precipitation. A total of $600 \mathrm{~mL}$ of $0.125-\mathrm{M}$ aqueous solution of $\left(\mathrm{NH}_{4}\right)_{2} \mathrm{CO}_{3}$ was poured into a jacket glass reactor $(1.25 \mathrm{~L}) ; 0.5-\mathrm{M}$ metal nitrates solutions were prepared, as were adequate volumes of each LSCM component regarding the desired final LSCM composition. The solutions were mixed to- gether and dripped into a stirring precipitant solution. The precipitating solution was kept at $60{ }^{\circ} \mathrm{C}$ under a $\mathrm{CO}_{2}$ protective atmosphere to prevent manganese oxidation during synthesis. The $\mathrm{pH}$ inside the jacket glass reactor was kept at $7.8 \pm 0.1$ by the periodic addition of ammonia (25\%, aq.). Afterwards, the precipitate was filtered off under a $\mathrm{CO}_{2}$ environment and washed three times $(50 \mathrm{~mL})$ with a $0.125-\mathrm{M}$ solution of $\left(\mathrm{NH}_{4}\right)_{2} \mathrm{CO}_{3}$, dried for $6 \mathrm{~h}$ at $110{ }^{\circ} \mathrm{C}$ and finally calcined at $1000{ }^{\circ} \mathrm{C}$ in an air atmosphere.

Table 1: Compositions and sample notations

Tabela 1: Sestave in poimenovanje vzorcev

\begin{tabular}{|c|c|}
\hline Sample composition & Sample name \\
\hline $\mathrm{La}_{0,7} \mathrm{Sr}_{0,3} \mathrm{Cr}_{0,5} \mathrm{Mn}_{0,5} \mathrm{O}_{3-\mathrm{d}}$ & $\mathrm{La} 7 \mathrm{Cr} 5$ \\
\hline $\mathrm{La}_{0,8} \mathrm{Sr}_{0,2} \mathrm{Cr}_{0,5} \mathrm{Mn}_{0,5} \mathrm{O}_{3-\mathrm{d}}$ & $\mathrm{La} 8 \mathrm{Cr} 5$ \\
\hline $\mathrm{La}_{0,9} \mathrm{Sr}_{0,1} \mathrm{Cr}_{0,5} \mathrm{Mn}_{0,5} \mathrm{O}_{3-\mathrm{d}}$ & $\mathrm{La} 9 \mathrm{Cr} 5$ \\
\hline $\mathrm{La}_{1} \mathrm{Cr}_{0,5} \mathrm{Mn}_{0,5} \mathrm{O}_{3-\mathrm{d}}$ & $\mathrm{La} 10 \mathrm{Cr} 5$ \\
\hline $\mathrm{LaCr}_{0,6} \mathrm{Mn}_{0,4} \mathrm{O}_{3}$ & $\mathrm{La} 10 \mathrm{Cr} 6$ \\
\hline $\mathrm{La}_{0,9} \mathrm{Sr}_{0,1} \mathrm{Cr}_{0,6} \mathrm{Mn}_{0,4} \mathrm{O}_{3}$ & $\mathrm{La} 9 \mathrm{Cr} 6$ \\
\hline $\mathrm{La}_{0,9} \mathrm{Sr}_{0,1} \mathrm{Cr}_{0,4} \mathrm{Mn}_{0,6} \mathrm{O}_{3}$ & $\mathrm{La} 9 \mathrm{Cr} 4$ \\
\hline $\mathrm{LaCr}_{0,4} \mathrm{Mn}_{0,6} \mathrm{O}_{3}$ & $\mathrm{La} 10 \mathrm{Cr} 4$ \\
\hline
\end{tabular}

The synthesized powders were milled in an agate mortar and un-axially pressed into pellets $(100 \mathrm{MPa})$ and sintered at various temperatures $\left(1250{ }^{\circ} \mathrm{C}, 1300{ }^{\circ} \mathrm{C}, 1400{ }^{\circ} \mathrm{C}\right.$ and $1500^{\circ} \mathrm{C}$ ) for $1 \mathrm{~h}$. The calcined and sintered samples were analysed with a PANalytical X'Pert PRO MPD apparatus. For the determination of the microstructure, the sintered tablets were polished (diamond pastes of 3 $\mu \mathrm{m}$ and $0.25 \mu \mathrm{m}$ ), thermally etched, and subsequently analysed with a FE-Zeiss ULTRA Plus SEM. The quantitative analyses of the microstructures were performed on digital images (images were digitized into pixels with 255 different grey values) using Axiovision 4.8 image-analysis software.

\section{RESULTS AND DISCUSSION}

The carbonate co-precipitation route is an appropriate method for the preparation of complex metal oxides, such as $\mathrm{La}_{1-\mathrm{x}} \mathrm{Sr}_{\mathrm{x}} \mathrm{Mn}_{1-\mathrm{y}} \mathrm{Cr}_{\mathrm{y}} \mathrm{O}_{3 \pm \delta}$ (LSCM). When the "reversed strike" co-precipitation method is used and the mixed solution of metal ions drips into the concentrated precipitant solution, the various cations within each droplet precipitate almost instaneously. ${ }^{18}$ Lanthanum carbonate precipitated at $\mathrm{pH}>4.2$, manganese carbonate at $\mathrm{pH}>5$ and strontium carbonate at $\mathrm{pH}>7.3$. Chromium precipitates as a hydroxide in a very narrow $\mathrm{pH}$ range from 6.6 to 7.3; however, $\mathrm{Cr}(\mathrm{OH})_{3}$ starts to dissolve at a $\mathrm{pH}$ value of 7.9. ${ }^{17}$ Therefore, the precipitation of mixed metal oxide should be carried out carefully in the tiny $\mathrm{pH}$ range from 7.3 and 7.9. If we take into account only simple carbonate and hydroxide species (Equations (1) to (4)) for the calculation for the stoichiometric amount of ammonium carbonate as a precipitant agent, we can conclude that an excess of $50 \%$ is used during the precipita- 
tion process. Thus, the super-saturation ratio in the case of the LSCM synthesis calculated from the molar ratio of ammonium carbonate and total metal ions is 1.5.

$$
\begin{aligned}
3\left(\mathrm{NH}_{4}\right)_{2} \mathrm{CO}_{3}+2 \mathrm{La}^{3+} \rightarrow \mathrm{La}_{2}\left(\mathrm{CO}_{3}\right)_{3}+6 \mathrm{NH}_{4}^{+} \\
\left(\mathrm{NH}_{4}\right)_{2} \mathrm{CO}_{3}+\mathrm{Sr}^{2+} \rightarrow \mathrm{SrCO}_{3}+2 \mathrm{NH}_{4}^{+} \\
3\left(\mathrm{NH}_{4}\right)_{2} \mathrm{CO}_{3}+\mathrm{Cr}^{3+}+\mathrm{H}_{2} \mathrm{O} \rightarrow \mathrm{Cr}(\mathrm{OH})_{3}+6 \mathrm{NH}_{4}^{+}+ \\
+3 \mathrm{HCO}_{3}^{-} \\
\left(\mathrm{NH}_{4}\right)_{2} \mathrm{CO}_{3}+\mathrm{Mn}^{2+} \rightarrow \mathrm{MnCO}_{3}+2 \mathrm{NH}_{4}^{+}
\end{aligned}
$$

According to Figure 1, the perovskite LSCM phase formation for all the samples is practically complete after calcination at $1000{ }^{\circ} \mathrm{C}$ for $1 \mathrm{~h}$ (the perovskite peaks are denoted with a letter "P"). The main perovskite phase is quite well crystallised. In the sample La7Cr5, with the highest $\mathrm{Sr}$ content and equal amounts of chromium and manganese, the XRD analysis revealed a small amount of strontium secondary phase $\mathrm{SrCrO}_{4}$ (denoted with the letter "S"). It is described in the literature that in the humidified hydrogen atmosphere $\mathrm{SrCrO}_{4}$ further transforms into the Ruddlesden-Popper phase $\mathrm{Sr}_{2} \mathrm{CrO}_{4}{ }^{9}$ Additionally, the X-ray powder diffraction indicates that in samples with the lowest $\mathrm{Cr}$ content (0.4), a lanthanumrich secondary phase $\mathrm{La}_{2} \mathrm{CrO}_{6}$ is formed (denoted with the letter "L"). Varying the $\mathrm{Sr}$ content in this $\mathrm{Cr}$-poor sample reveals that in the $\mathrm{Sr}$-free and $\mathrm{Sr}=0.1$ samples the $\mathrm{La}_{2} \mathrm{CrO}_{6}$ content determined according to the Rietveld refinement is $3.1 \%$ and $7.6 \%$, respectively. Multiple RTG peaks observed in some patterns are a consequence of a perovskite lattice superstructure. This lattice superstructure is formed due to the octahedron tilting, which has its origin in the random Sr-incorporation into the perovskite structure. ${ }^{19,20}$ By doping lanthanum-manganite with $\mathrm{Sr}$ and $\mathrm{Cr}$, the symmetry of the structure is lowered due to the different sizes of the introduced cations compared to the original ions. Consequently, octahedrons defined by a central cation (B-site cation) and

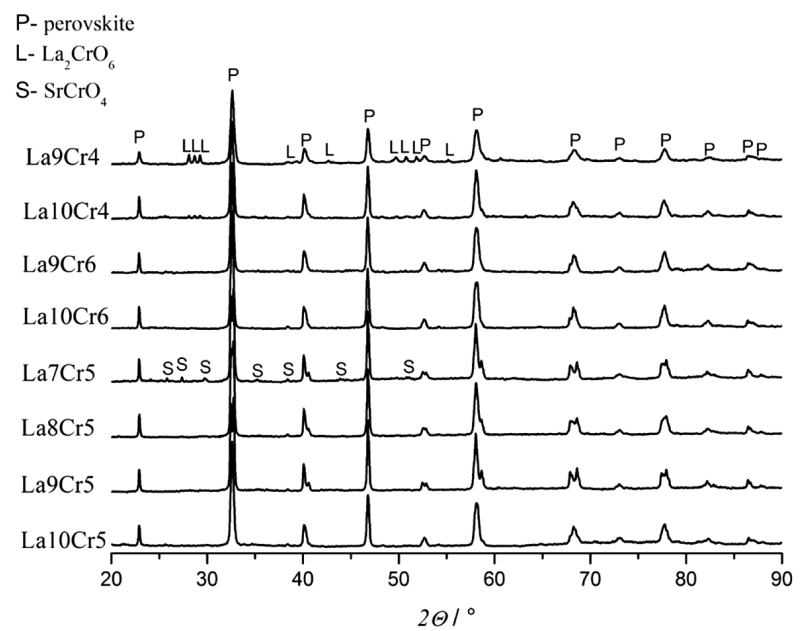

Figure 1: X-ray diffraction patterns of prepared samples after calcination at $1000{ }^{\circ} \mathrm{C}$

Slika 1: Rentgenogram pripravljenih vzorcev po kalcinaciji pri $1000{ }^{\circ} \mathrm{C}$

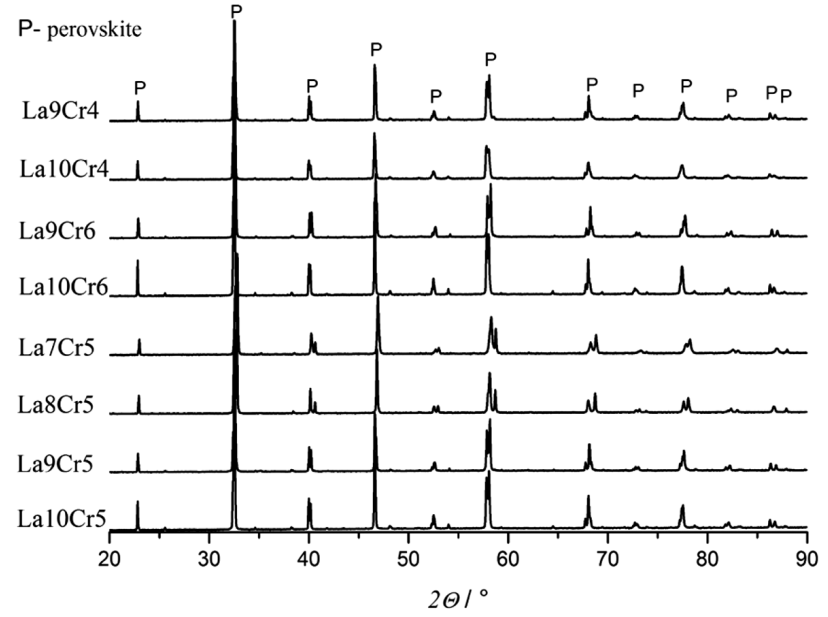

Figure 2: X-ray diffraction patterns of all samples after calcination at $1250{ }^{\circ} \mathrm{C}$

Slika 2: Rentgenogram vseh vzorcev po kalcinaciji pri $1250{ }^{\circ} \mathrm{C}$

the surrounding oxygen ions are slightly tilted and the repeating structure pattern is defined by eight original unit cells

The secondary phases are highly undesired in the final LSCM since they result in the so-called layered perovskite structure with additional layers of Sr-oxide, La-oxide, or a mixture of both separating the LSCM at temperatures around $1100{ }^{\circ} \mathrm{C}$ and in a $\mathrm{H}_{2}$ atmosphere. Furthermore, the secondary phases decrease the thermochemical stability, catalytic activity and electrical conductivity of the LSCM..$^{9,12}$
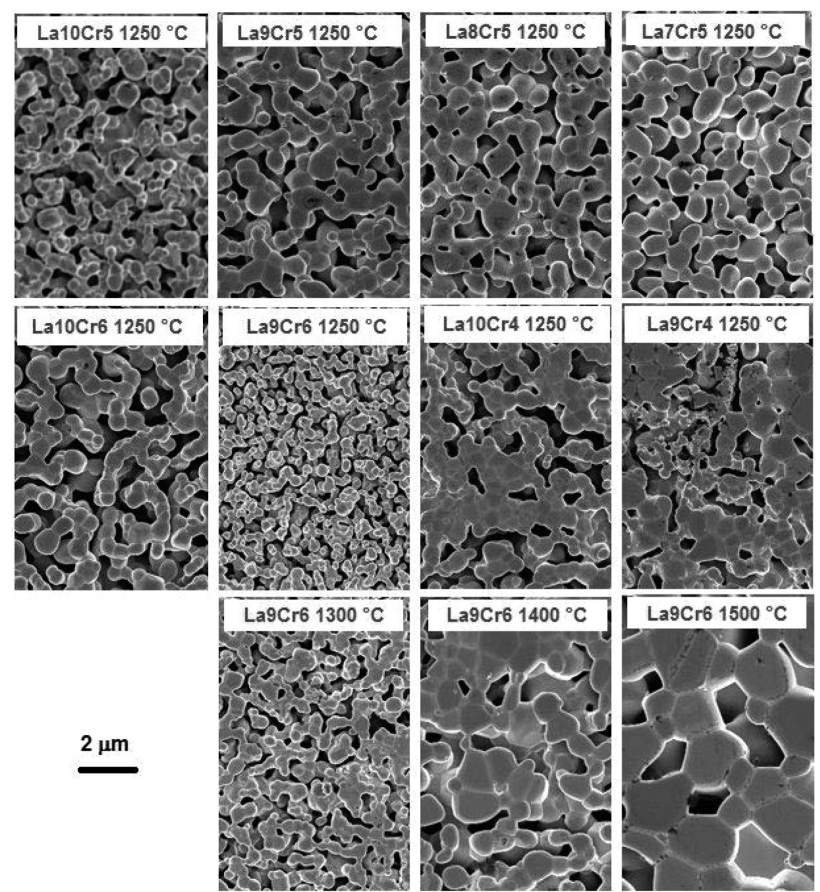

Figure 3: SEM micrographs of all samples sintered at $1250{ }^{\circ} \mathrm{C}$ and sample La9Cr6 sintered at $1250{ }^{\circ} \mathrm{C}, 1300{ }^{\circ} \mathrm{C}, 1400{ }^{\circ} \mathrm{C}$ and $1500{ }^{\circ} \mathrm{C}$

Slika 3: SEM-posnetki vseh vzorcev po sintranju pri $1250{ }^{\circ} \mathrm{C}$ in vzorca La9Cr6, sintranega pri $1250{ }^{\circ} \mathrm{C}, 1300{ }^{\circ} \mathrm{C}, 1400{ }^{\circ} \mathrm{C}$ in $1500{ }^{\circ} \mathrm{C}$ 
Table 2: Results of quantitative microstructure analysis of the sintered samples Tabela 2: Rezultati kvantitativne analize mikrostrukture sintranih vzorcev

\begin{tabular}{|c|c|c|c|c|c|c|c|c|c|c|}
\hline & $T /{ }^{\circ} \mathrm{C}$ & $\varepsilon / \%$ & $d_{y} / \mu \mathrm{m}$ & $d_{x} / \mu \mathrm{m}$ & $\bar{d} / \mu \mathrm{m}$ & $\psi$ & $S_{\text {pore }} / \mu \mathrm{m}^{2}$ & $\begin{array}{c}F E R E T_{\mathrm{MAX}} \\
/ \mu \mathrm{m}\end{array}$ & $\begin{array}{l}\rho_{\text {teor }} / \\
\mathrm{g} \mathrm{cm}^{-3}\end{array}$ & $\rho_{\text {rel }} / \%$ \\
\hline \multirow{4}{*}{ La10Cr5 } & 1250 & 51.9 & 0.30 & 0.31 & 0.28 & 0.67 & 0.44 & 1.02 & \multirow{4}{*}{6.71} & 48.1 \\
\hline & 1300 & 50.9 & 0.43 & 0.44 & 0.41 & 0.74 & 0.86 & 1.66 & & 49.1 \\
\hline & 1400 & 40.1 & 1.00 & 1.01 & 0.92 & 0.73 & 1.31 & 2.03 & & 59.9 \\
\hline & 1500 & 27.4 & 1.85 & 1.91 & 1.70 & 0.70 & 1.27 & 1.82 & & 72.6 \\
\hline \multirow{4}{*}{ La9Cr5 } & 1250 & 44.6 & 0.52 & 0.53 & 0.48 & 0.70 & 0.77 & 1.69 & \multirow{4}{*}{6.60} & 55.4 \\
\hline & 1300 & 41.5 & 0.60 & 0.61 & 0.55 & 0.71 & 0.72 & 1.60 & & 58.5 \\
\hline & 1400 & 25.4 & 1.10 & 1.11 & 1.02 & 0.74 & 0.58 & 1.26 & & 74.6 \\
\hline & 1500 & 9.9 & 2.89 & 2.92 & 2.67 & 0.69 & 0.39 & 0.65 & & 90.1 \\
\hline \multirow{4}{*}{$\mathrm{La} 8 \mathrm{Cr} 5$} & 1250 & 43.7 & 0.50 & 0.49 & 0.45 & 0.70 & 0.36 & 1.05 & \multirow{4}{*}{6.56} & 56.3 \\
\hline & 1300 & 40.3 & 0.62 & 0.60 & 0.55 & 0.67 & 0.20 & 0.76 & & 59.7 \\
\hline & 1400 & 27.0 & 1.22 & 1.25 & 1.14 & 0.74 & 0.77 & 1.46 & & 73.0 \\
\hline & 1500 & 16.0 & 2.54 & 2.65 & 2.35 & 0.72 & 0.65 & 1.12 & & 84.3 \\
\hline \multirow{4}{*}{$\mathrm{La} 7 \mathrm{Cr} 5$} & 1250 & 45.9 & 0.56 & 0.58 & 0.53 & 0.72 & 0.37 & 0.80 & \multirow{4}{*}{6.45} & 54.1 \\
\hline & 1300 & 42.1 & 0.86 & 0.86 & 0.79 & 0.76 & 0.74 & 1.04 & & 57.9 \\
\hline & 1400 & 31.2 & 1.23 & 0.86 & 1.14 & 0.75 & 0.66 & 1.47 & & 68.8 \\
\hline & 1500 & 21.8 & 1.94 & 2.00 & 1.79 & 0.73 & 0.39 & 0.87 & & 78.2 \\
\hline \multirow{4}{*}{ La10Cr6 } & 1250 & 54.2 & 0.44 & 0.45 & 0.42 & 0.72 & 1.12 & 1.42 & \multirow{4}{*}{6.72} & 45.8 \\
\hline & 1300 & 48.1 & 0.76 & 0.77 & 0.72 & 0.75 & 1.33 & 1.92 & & 51.9 \\
\hline & 1400 & 37.9 & 1.20 & 1.21 & 1.13 & 0.77 & 1.33 & 2.06 & & 62.1 \\
\hline & 1500 & 23.4 & 1.97 & 1.96 & 1.84 & 0.76 & 1.94 & 2.31 & & 76.6 \\
\hline \multirow{4}{*}{ La9Cr6 } & 1250 & 54.0 & 0.24 & 0.23 & 0.22 & 0.79 & 0.37 & 1.07 & \multirow{4}{*}{6.57} & 46.0 \\
\hline & 1300 & 50.5 & 0.39 & 0.39 & 0.36 & 0.79 & 3.10 & 2.73 & & 49.5 \\
\hline & 1400 & 40.7 & 0.67 & 0.69 & 0.63 & 0.76 & 2.54 & 2.94 & & 59.3 \\
\hline & 1500 & 38.6 & 1.70 & 1.73 & 1.60 & 0.78 & 1.35 & 2.02 & & 61.4 \\
\hline \multirow{4}{*}{ La10Cr4 } & 1250 & 44.5 & 0.40 & 0.41 & 0.38 & 0.78 & 0.59 & 1.11 & \multirow{4}{*}{6.73} & 55.5 \\
\hline & 1300 & 39.2 & 0.77 & 0.78 & 0.72 & 0.71 & 0.36 & 1.01 & & 60.8 \\
\hline & 1400 & 31.6 & 1.21 & 1.19 & 1.11 & 0.72 & 0.83 & 1.42 & & 68.4 \\
\hline & 1500 & 24.0 & 2.15 & 2.09 & 1.94 & 0.70 & 1.11 & 1.47 & & 76.0 \\
\hline \multirow{4}{*}{ La9Cr4 } & 1250 & 54.1 & 0.43 & 0.43 & 0.40 & 0.72 & 2.63 & 2.76 & \multirow{4}{*}{6.59} & 45.9 \\
\hline & 1300 & 50.7 & 0.69 & 0.67 & 0.64 & 0.73 & 1.65 & 2.43 & & 49.3 \\
\hline & 1400 & 34.1 & 1.43 & 1.44 & 1.33 & 0.76 & 2.30 & 2.65 & & 65.9 \\
\hline & 1500 & 22.5 & 2.68 & 2.60 & 2.44 & 0.75 & 1.13 & 1.18 & & 77.5 \\
\hline
\end{tabular}

After the sintering at $1250{ }^{\circ} \mathrm{C}$, the only phase present in all the samples is the LSCM perovskite, as shown in Figure 2. The absence of secondary phases indicates that they re-dissolve in the main LSCM phase when the sintering temperature is increased. This discovery also gives a very effective tool for controlling the amount of secondary phases in LSCM or even eliminates them completely. Due to the possibility of eliminating the secondary phases from the LSCM, it is reasonable to conclude that the co-precipitation method offers an essential advantage over the synthesis processes that are based on the solid-state reactions in which local inhomogeneity in chemical composition are quite common.

One of the major challenges in applying LSCM material as an anode in ceramic fuel cells is achieving the continuity of the electrode material as well as the continuity of the pores. Good contact between the particles is critical for forming continuous paths throughout the formed anode, reaching a high conductivity. The sintering behaviour of all the samples after sintering at $1250{ }^{\circ} \mathrm{C}$ is demonstrated in Figure 3. Since all the microstructure parameters that are important for an exact anode analysis are sometimes difficult to deduce simply from the SEM micrographs, a detailed quantitative microstructure analysis of sintered samples is performed. For statistically reliable data in each case, 5 to 10 different regions were analyzed. The results of the quantitative microstructure analysis are summarized in Table 2 . The parameters $\bar{d}, d_{x}, d_{y}$ and $\psi$ are represented as the diameter of the area-analogue circle $-D_{\text {circle }}$, the intercept lengths in the $x$ and $y$ directions - FERET $T_{X}, F E R E T_{Y}$ and the Shape factor $f_{\text {circle. }} S_{\text {pore }}$ and FERET $T_{\text {MAX }}$ are determined as the pore areas and maximum intercept lengths of the pore while $\rho_{\text {rel }}$ and $\varepsilon$ are determined from the geometric densities of the tablets and the theoretical densities that were calculated using the Rietveld refinement.

SEM micrographs sintered at $1250{ }^{\circ} \mathrm{C}$ reveal that the microstructure parameters greatly depend on the sample composition. When comparing samples with equal amounts of $\mathrm{Cr}$ and $\mathrm{Mn}$ with various $\mathrm{Sr}$ contents we can observe that the presence of strontium promotes sintering. It is also evident that the grains are larger in samples 
that contain Sr than in the Sr-free sample. Although no secondary phases are detected in the Sr-free sample (La10Cr5), the microstructure is composed of regions with larger and smaller grains. All Sr-free samples with a lower Cr-content behave similarly. The presence of a secondary phase $\mathrm{SrCrO}_{4}$ in the sample with the highest Sr content (La7Cr5) evidently does not have a significant effect on the LSCM grain size distribution. In contrast, the presence of a lanthanum-rich secondary phase $\mathrm{La}_{2} \mathrm{CrO}_{6}$ in samples with a lower $\mathrm{Cr}$ content (La10Cr4 and La9Cr4) causes non-homogenous microstructures with the denser regions containing larger grains and the less dense regions containing smaller grains. In the phase-pure LSCM sample with a $\mathrm{Cr}$ content $y=0.6$ (La9Cr6), a very interesting microstructure is formed after sintering at $1250{ }^{\circ} \mathrm{C}$. In this sample, the formation of well-connected fine grains is observed.

The results of a quantitative microstructural analysis are in good agreement with optical observations. The relative sintered density increases and the porosity decreases with the increasing sintering temperature. Samples with a Sr content $x=0.1,0.2$ or 0.3 and equal contents of $\mathrm{Cr}$ and $\mathrm{Mn}$ sinter at the lowest sintering temperature of $1250{ }^{\circ} \mathrm{C}$ to somewhat higher densities than the $\mathrm{Sr}$-free sample (La10Cr5). At the same sintering temperature, $\rho_{\text {rel }}$ reaches $48.1 \%, 55.4 \%, 56.3 \%$ and $54.1 \%$ for the samples $\mathrm{La} 10 \mathrm{Cr} 5, \mathrm{La} 9 \mathrm{Cr} 5 \mathrm{La} 8 \mathrm{Cr} 5$ and $\mathrm{La} 7 \mathrm{Cr} 5$, respectively. The addition of strontium to the perovskite also results in grain growth, during which grains reach an average size of $0.28 \mu \mathrm{m}$ at $1250{ }^{\circ} \mathrm{C}$ in a $\mathrm{Sr}$-free sample, while for the highest $\mathrm{Sr}$ content in sample $x=0.3$ the average grain size grew to $0.53 \mu \mathrm{m}$. At the highest sintering temperature $\left(1500{ }^{\circ} \mathrm{C}\right), \rho_{\text {rel. }}$ reaches $90.1 \%, 72.6 \%$, $84.3 \%$ and $78.2 \%$ for the samples La9Cr5, La10Cr5, $\mathrm{La} 8 \mathrm{Cr} 5$ and La7Cr5, respectively. From this fact, it can be deduced that the addition of $\mathrm{Sr}$ to some amount $x=$ 0.1 accelerates sintering, while adding $\mathrm{Sr}$ to perovskite above a certain concentration $x=0.2$ and 0.3 supresses the densifying process. At a lower $\mathrm{Sr}$ concentration, $\mathrm{SrCrO}_{4}$ (according to phase diagram $\mathrm{SrO}-\mathrm{Cr}_{2} \mathrm{O}_{3}$ ) forms a liquid phase due to eutectic and peritectic reactions ${ }^{21}$ that promote sintering. ${ }^{22}$ In principle, a higher Sr-content increases the amount of $\mathrm{SrCrO}_{4}$ phase which reacts to the liquid phase and secondary solid phase through a peritectic transformation. This secondary solid phase hinders sintering. A higher sintering temperature also results in pronounced grain growth in which originally sub-micrometre grains grow to almost $\sim 2.7 \mu \mathrm{m}$ in size at $1500{ }^{\circ} \mathrm{C}$. With this pronounced growth the grains become less similar to an ideal sphere, which is manifested as a slight decrease in the shape factor. Similar behaviour was observed for the sintering of a combustion-derived LSCM ceramic. $^{23}$

In the LSCM phase, with a pure sample ( $\mathrm{La} 9 \mathrm{Cr} 6)$ with $\mathrm{Cr}$ content $y=0.6$ and a low Sr-addition, the formation of well-connected grains is observed after sintering at $1250{ }^{\circ} \mathrm{C}$. With increasing sintering temperature, the densification process normally advances and the grains grow; however, the grain growth is somehow less pronounced than that in other samples. The average grain size for sample La9Cr6 sintered at various temperatures $1250{ }^{\circ} \mathrm{C}, 1300{ }^{\circ} \mathrm{C}, 1400{ }^{\circ} \mathrm{C}$ and $1500{ }^{\circ} \mathrm{C}$ is $0.22 \mu \mathrm{m}, 0.36$ $\mu \mathrm{m}, 0.63 \mu \mathrm{m}$ and $1.6 \mu \mathrm{m}$, respectively. Furthermore, for the sample La9Cr6, a calculation of the average $F E R E T_{\text {MAX }}$ of pores versus the grain diameter gives the highest value among all the samples. Since the average pore diameter is comparable at sintering temperature $1250{ }^{\circ} \mathrm{C}$ in all samples, this value somehow indicates a low average LSCM grain size and pore appearance in the sample, which contribute mainly to the open porosity. This fact together with the absolute value of porosity is very important from the practical point of view if such material is to be used as an anode layer in the operating SOFC. In order to form a continuous phase of pores in sintered samples, the porosity should be at least 30 vol.\%, while the pore appearance should contribute to open porosity to keep the LSCM anode layer permeable for gases.

Several very important findings arise from the quantitative microstructure analysis of LSCM samples. Regarding sintering optimisation, a lower Sr content $(x=$ $0.1)$ with a somewhat higher chromium content $(y=0.6)$ (sample La9Cr6) leads to proper microstructure formation at $1250{ }^{\circ} \mathrm{C}$, where the grain-to-grain contact area is enlarged, making it progressively easier to find a solid continuous path of LSCM throughout the sample. At the same time, the appropriate porosity is preserved and the average grain size is the smallest, thus enlarging the interface area where gaseous reactants meet the electrocatalytic solid surface in a potential fuel cell. With additional information from the literature ${ }^{10}$ regarding LSCM catalytic activity toward $\mathrm{H}_{2}$ oxidation, it can be concluded that $\mathrm{La}_{0,9} \mathrm{Sr}_{0,1} \mathrm{Cr}_{0,6} \mathrm{Mn}_{0,4} \mathrm{O}_{3}$ is the most appropriate LSCM chemical composition, which will also ensure the desired microstructure characteristics at the relatively low sintering temperature of $1250{ }^{\circ} \mathrm{C}$.

\section{CONCLUSIONS}

$\mathrm{La}_{1-\mathrm{x}} \mathrm{Sr}_{\mathrm{x}} \mathrm{Mn}_{1-\mathrm{y}} \mathrm{Cr}_{\mathrm{y}} \mathrm{O}_{3 \pm \delta}$ perovskite materials ( $x$ from 0 to 0.3 and $y$ from 0.4 to 0.6 ) were prepared using the "reverse strike" carbonate co-precipitation method, which has been shown to be an appropriate method since it allows good control over the reaction system and the preparation of LSCM materials with various compositions.

After calcination of the precipitated mixed carbonate-hydroxide precursors at $1000^{\circ} \mathrm{C}$, the main crystalline phase in all the samples is LSCM perovskite. In the sample with the highest $\operatorname{Sr}$ content $(x=0.3)$ and equal amounts of chromium and manganese $(y=0.5)$, a strontium secondary phase $\mathrm{SrCrO}_{4}$ was detected, while in samples with a lower $\mathrm{Cr}$ content $(y=0.4)$ a lanthanumrich secondary phase $\mathrm{La}_{2} \mathrm{CrO}_{6}$ is formed. After sintering at $1250{ }^{\circ} \mathrm{C}$, the secondary phase re-dissolved into the perovskite. 
Microstructure parameters for the LSCM ceramics greatly depend on the sample composition. In samples with equal contents of $\mathrm{Cr}$ and $\mathrm{Mn}$, a slight addition of $\mathrm{Sr}$ $(x=0.1)$ accelerates the sintering, while adding Sr to the perovskite above a concentration of $x=0.2$ supresses the densifying process. In samples with a lower $\mathrm{Cr}$ content $(x=0.4)$, the presence of a lanthanum-rich secondary phase $\mathrm{La}_{2} \mathrm{CrO}_{6}$ causes non-homogenous microstructures to form.

Samples with a lower Sr content $(x=0.1)$ and a somewhat higher chromium content $(y=0.6)$ (La9Cr6) lead to appropriate microstructure formation at sintering temperatures as low as $1250{ }^{\circ} \mathrm{C}$. Such a composition and sintering temperature are also recognized as the most appropriate parameters for suitable LSCM material.

\section{REFERENCES}

${ }^{1}$ A. Atkinson, S. Barnett, R. J.Gorte, J. T. D. Irvine, A. J. McEvoy, M. Mogensen, S. C. Singhal, J. Vohs, Advanced anodes for high temperature fuel cells, Nat. Materials, 3 (2004), 17-24, doi:10.1038/ nmat 1040

${ }^{2}$ C. Sun, U. Stimming, Recent anode advances in solid oxide fuel cells, J. Pow. Sources, 171 (2007), 247-260, doi:10.1016/j.jpowsour. 2007.06.086

${ }^{3}$ H. Hurokawa, T. Z. Sholklaper, C. P. Jacobson, L. C. De Jonghe, S. J. Visco, Ceria nanocoating for sulphur tolerant Ni-based anodes of solid oxide fuel calls, Electrochem.Solid State, 100 (2007), 135-138, doi:10.1149/1.2748630

${ }^{4}$ S. Macintosh, R. J. Gorte, Direct hydrocarbon solid oxide fuel cells, Chem. Rev., 104 (2004), 4845-4865, doi:10.1021/cr020725g

${ }^{5} \mathrm{~S}$. Tao, J. T. S. Irvine, A redox-stable efficient anode for solid-oxide fuel cells, Nat. Mater., 2 (2003), 320-322, doi:10.1038/nmat871

${ }^{6}$ W. Zhu, D. Ding, C. Xia, Enhancement in Three-Phase Boundary of SOFC Electrodes by an Ion Impregnation Method: A Modeling Comparison, Electrochem. Solid-State Lett., 11 (2008), B83-B86, doi:10.1149/1.2895009

${ }^{7} \mathrm{~S}$. Tao, J. T. S. Irvine, Synthesis and characterization of $\mathrm{La}_{0.75} \mathrm{Sr}_{0.25} \mathrm{Cr}_{0.5} \mathrm{Mn}_{0.5} \mathrm{O}_{3-\delta}$, a redox stable, efficient perovskite anode for SOFCs, J. Electrochem. Soc., 151 (2004), 252-259, doi:10.1149/1.1639161

${ }^{8}$ C. Lu, W. L. Worrell, J. M. Vohs, R. J. Gorte, A Comparison of $\mathrm{Cu}-\mathrm{Ceria-SDC}$ and Au-Ceria-SDC Composites for SOFC Anodes, J. Electrochem. Soc., 150 (2003), A1357-A1359, doi:10.1149/ 1.1608003

${ }^{9}$ L. Deleebeeck, J. L. Fournier, V. Birss, Comparison of Sr-doped and Sr-free $\mathrm{La}_{1-\mathrm{x}} \mathrm{Sr}_{\mathrm{x}} \mathrm{Mn}_{0.5} \mathrm{Cr}_{0.5} \mathrm{O}_{3 \pm \delta}$ SOFC Anodes, Solid State Ionics, 181 (2010), 1229-1237, doi:10.1016/j.ssi.2010.05.027
${ }^{10}$ L. Deleebeeck, J. L. Fournier, V. Birss, Catalysis of the hydrogen oxidation reactions by $\mathrm{Sr}$-doped $\mathrm{LaMn}_{1-\mathrm{y}} \mathrm{Cr}_{\mathrm{y}} \mathrm{O}_{3 \pm \delta}$ oxides, Solid State Ionics, 203 (2011), 69-79, doi:10.1016/j.ssi.2011.07.017

${ }^{11}$ J. Wan, J. H. Zhu, J. B. Goodenough, $\mathrm{La}_{0.75} \mathrm{Sr}_{0.25} \mathrm{Cr}_{0.5} \mathrm{Mn}_{0.5} \mathrm{O}_{3-d}+\mathrm{Cu}$ composite anode running on $\mathrm{H}_{2}$ and $\mathrm{CH}_{4}$ fuels, Solid State Ionics, 177 (2006), 1211-121, doi:10.1016/j.ssi.2006.04.046

${ }^{12}$ S. P. Jiang, L. Zhang, Y. Zhang, Lanthanum strontium manganese chromite cathode and anode synthesized by gel-casting for solid oxide fuel cells, J. Mater. Chem., 17 (2007), 2627-2635, doi:10.1039/ b701339f

${ }^{13}$ M. A. Raza, I. Z. Rahman, S. Beloshapkin, Synthesis of nanoparticles of $\mathrm{La}_{0.75} \mathrm{Sr}_{0.25}$ ? $\mathrm{Cr}_{0.5} \mathrm{Mn}_{0.5} \mathrm{O}_{3-\delta}$ (LSCM) perovskite by solution combustion method for solid oxide fuel application, Journal of Alloys and Compounds, 485 (2009), 593-597, doi:10.1016/j.jallcom. 2009.06.059

${ }^{14}$ S. Zha, P. Tsang, Z. Cheng, M. Liu, Electrical properties and sulfur tolerance of $\mathrm{La}_{0.75} \mathrm{Sr}_{0.25} \mathrm{Cr}_{1-x} \mathrm{Mn}_{x} \mathrm{O}_{3}$ under anodic conditions, J. Solid State Chem, 178 (2005), 1844-1850, doi:10.1016/j.jssc.2005.03.027

${ }^{15}$ D. M. Bastidas, S. Tao, J T. S. Irvine, A symmetrical solid oxide fuel cell demonstrating redox stable perovskite electrodes. J. Mater. Chem., 16 (2006), 1603-1605, doi:10.1039/b600532b

${ }^{16}$ B. Huang, S. R. Wang, R. Z. Liu, X. F. Ye, H. W. Nie, X. F. Sun, T. L. Wen, Performance of $\mathrm{La}_{0.75} \mathrm{Sr}_{0.25} \mathrm{Cr}_{0.5} \mathrm{Mn}_{0.5} \mathrm{O}_{3-\delta}$ perovskite-structure anode material at lanthanum gallate electrolyte for IT-SOFC running on ethanol fuel, J. Power Sources, 167 (2007), 39-46, doi:10.1016/j.jpowsour.2007.02.022

${ }^{17}$ R. Pelosato, C. Cristiani, G. Dotelli, M. Mariani, A. Donazzi, I. N. Sora, Co - precipitation synthesis of SOFC electrode materials, International Journal of Hydrogen Energy, 38 (2013), 480-491, doi:10.1016/j.ijhydene.2012.09.063

${ }^{18}$ B. H. Sang, C. Pyeong-Seok, H. C. Yoon, L. Dokyol, L. Jong-Heun, Preparation of $\mathrm{La}_{0.75} \mathrm{Sr}_{0.25} \mathrm{Cr}_{0.5} \mathrm{Mn}_{0.5} \mathrm{O}_{3-\delta}$ fine powders by carbonate coprecipitation for solid oxide fuel cells, J. Power Sources, 195 (2010), 124-129, doi:10.1016/j.jpowsour.2009.06.078

${ }^{19}$ A. M. Glazer, The Clasisification of Tilted octahedra in Perovskites, Acta Cryst., B28 (1972), 3384-3392

${ }^{20}$ Noel W. Thomas, A. Beitollahi, Inter-Relationship of Octahedral Geometry, Polyhedral Volume Ratio and Ferroelectric Properties in Rombohedral Perovskites, Acta Cryst., B50 (1994), 549-560

${ }^{21}$ E. M. Levin, H. F. McMurdie, Phase Diagrams for Ceramists, The American Ceramic Society, 1975, p. 29

${ }^{22}$ P. H. Duvigneaud, Factors Affecting the Sintering and the Electrical Properties of Sr-Doped $\mathrm{LaCrO}_{3}$, J. European Cer. Soc., 14 (1994), 359-367, doi:10.1016/0955-2219(94)90073-6

${ }^{23}$ K. Zupan, M. Marinšek, Combustion Derived $\mathrm{La}_{1-\mathrm{x}} \mathrm{Sr}_{\mathrm{x}} \mathrm{Mn}_{0,5} \mathrm{Cr}_{0,5} \mathrm{O}_{3 \pm \delta}$ $(x=0.20,0.25)$ Perovskite: Preparation, Properties, Characterization, Mater. Tehnol., 48 (2014), 885-891 